\title{
Tithonia diversifolia Leaves and Stems Use as Substrate Amendment Promote the Growth of Plantain Vivoplants in the Nursery
}

\author{
C. A. Ewané1,2* $\mathbb{1}$, N. T. Mbanya1', T. Boudjeko ${ }^{1,2}$ \\ ${ }^{1}$ Laboratory of Phytoprotection and Plant Valorization, Biotechnology Center, University of Yaoundé 1, \\ Yaoundé, Cameroon \\ ${ }^{2}$ Department of Biochemistry, Faculty of Science, University of Yaoundé 1, Yaoundé, Cameroon \\ Email: *ccilany.ewane@gmail.com
}

How to cite this paper: Ewané, C.A., Mbanya, N.T. and Boudjeko, T. (2020) Tithonia diversifolia Leaves and Stems Use as Substrate Amendment Promote the Growth of Plantain Vivoplants in the Nursery. Agricultural Sciences, 11, 849-859.

https://doi.org/10.4236/as.2020.119054

Received: August 18, 2020

Accepted: September 26, 2020

Published: September 29, 2020

Copyright ( 2020 by author(s) and Scientific Research Publishing Inc. This work is licensed under the Creative Commons Attribution International License (CC BY 4.0).

http://creativecommons.org/licenses/by/4.0/

\begin{abstract}
Tithonia diversifolia is a year-round weed that decomposes rapidly after application as a soil amendment and it is more and more used in agriculture due to its numerous properties. The use of Tithonia diversifolia in the production of plantain vivoplants is a great opportunity for small holders' farmers that cannot easily buy chemical inputs for yield improvement. All plant parts are used because of their richness in nutrients, mineral elements and phytochemicals without knowing which part is the most efficient. Tithonia diversifolia used as substrate amendment for plantain vivoplants production in nursery could promote their growth. This study aims to evaluate the effect of $T$. diversifolia leaves and stems as substrate amendment on plantain vivoplants growth promotion. The vivoplants were produced in substrates amended with $T$. diversifolia leaves, stems, combination of leaves and stems, and control without amendment. The vegetative growth parameters (number of shoots, height and diameter of shoots, area of shoots leaves) were assessed in sterilized substrate and unsterilized substrate conditions. T. diversifolia leaves and stems treatment increases the number of shoots, the height and the diameter of shoots as well as the area of shoots leaves compared to the control. T. diversifolia stems are the more efficient treatment, followed by the combination of $T$. diversifolia leaves and stems and finally the $T$. diversifolia leaves. They act as a biofertilizer promoting thus, the growth of plantain vivoplants in the nursery. All parts of Tithonia diversifolia can therefore be used by poor small holder farmers, as green manure for soil amendment in a green agriculture context.
\end{abstract}




\section{Keywords}

Plantain Vivoplants, Tithonia diversifolia, Substrate Amendment, Growth Promotion, Biofertilizer

\section{Introduction}

Tithonia diversifolia (Asteraceae family) is a year-round weed that grows abundantly along road paths, boundaries and on abandoned farmland throughout the tropics and subtropics. T. diversifolia plays an important role in crops nutrition and control due to its biofertilising and antifungal properties respectively [1] [2] [3] [4]. Indeed, it is rich in nutrients, such as nitrogen, phosphorus and potassium; and defense metabolites, such as flavonoids, tannins, alkaloids, PR-proteins for plants defense [1] [3] [4] [5] [6] [7]. The leaves, the stems, and the roots of $T$. diversifolia also contain some phytochemicals such as sesquiterpenoids, diterpenoids, alkaloids, flavonoids, chlorogenic acid derivatives, phenols, saponins, tannins and terpenoids [6] [7]. T. diversifolia decomposes rapidly after application as a soil amendment to maintain and improve the physical, chemical and biological properties of the soil and also increase the availability of nutrients [5]. The addition of natural inputs based on Tithonia diversifolia could be a solution to improve the growth of vivoplants while reducing the impact of chemical inputs in banana cultivation.

Banana belongs to the Musaceae family (Musa spp.) and is a perennial monocotyledonous plant originated from South East Asia. It requires the tropical and subtropical conditions for its good development. Among the numerous Musaceae family cultivars, plantains play a vital role in contributing in one hand to food security in Central and West Africa, and in another hand to income generation for millions of people in these regions [8]. Indeed, it is rich in energy, mineral, dietary fiber and vitamins. Cameroon is ranked $3^{\text {rd }}$ in the world (3.94 millions of tons per year) in terms of plantain production and the first in the Central African Economic and Monetary Community (CEMAC) zone [9]. Plantain production is very low to cover the large demand and there is a need to create new plantations despite the unavailability of seedlings in quantity and quality [10].

Plantains seedlings usually come from suckers extracted from former plantation which could be contaminated with pathogenic microorganisms. The vitroplants are not affordable to small holder farmers, whereas, vivoplants are an innovative alternative. They are also called "PIF" (Plants Issus de Fragment de tiges) that is plantlets from stem bits and were developed by the Centre Africain de Recherches sur Bananiers et Plantains (CARBAP) [10] [11]. Despite their numerous advantages, vivoplants are facing many problems during acclimatization in the farm and it's important to strengthen them during their production with some inputs. However, the use of chemical inputs (weed-killers, fertilizers, 
fungicides and pesticides) in the nursery and on farmlands is expensive for small peasant farmers. In addition, they are harmful to human and the environment, responsible for the appearance of the residues in fruits skin and vegetables as well as resistance in plant pathogens strains [12].

Recent studies have demonstrated that the application on the substrates of clam shell powder associated with $T$. diversifolia and $T$. diversifolia mulch, the watering with $T$. diversifolia liquid extract have a strong influence on plantain vivoplants growth and susceptibility to black Sigatoka disease (BSD) in nurseries [13] [14] [15] [16]. However, T. diversifolia leaves and stems have not yet been used in the substrate alone and none is known about the plant part effect on vivoplants growth promotion. The aim of this study was to evaluate the soil amendment with Tithonia diversifolia leaves and stems effect on the promotion of plantain vivoplants growth in the nursery.

\section{Materials and Methods}

\subsection{Materials}

In the Mbam and Kim division of the Centre region of Cameroon, plantain (Musa spp., genome AAB) suckers of Big-Ebanga variety were collected. This variety was selected due to his short cycle of production and his capacity to produce a great number of plantain seedlings. Around the Biotechnology Centre of University of Yaoundé 1 located at Nkolbisson (Yaoundé-Cameroon), T. diversifolia stems and leaves were collected, as well as the sawdust, sand and black soil used to formulate the vivoplants substrates.

The young stems and mature leaves were collected, dried under the sun and then flaked with the hands while the sawdust, sand and black soil were sterilized in an oven at different temperatures and time intervals as described by [10]. In the greenhouse with mean temperature between $25^{\circ} \mathrm{C}$ and $28^{\circ} \mathrm{C}$, the germination and emergence stage of vivoplants were done on the sawdust while in the shade, it was the sand and the black soil in proportions of $1 / 3$ and $2 / 3$ for vegetative growth.

\subsection{Experimental Design}

This study was conducted in Yaoundé (Centre Region of Cameroon) between August 2016 to March 2017. The research was carried out in two completely randomized blocks with four (04) modalities in each block in the greenhouse and in the shade. The two blocks types were Sterilized Substrate (SS) and unSterilized Substrate (uSS). Between the four modalities, three were based on Tithonia diversifolia and one on control: 1) control only, 2) T. diversifolia leaves, 3) $T$. diversifolia stems and 4) T. diversifolia leaves and stems.

In each block, each modality was considered as an Experimental Unit (EU). In each EU, six (06) explants were introduced and covered with a white transparent plastic paper in the greenhouse. The vivoplants were prepared following the method used by [10]. 


\subsection{Evaluation of $T$. diversifolia Leaves and Stems Effect on Vivoplants Growth}

For each modality in the greenhouse, the shoots number was assessed after every seven days starting from the second week of explants introduction and was done for a period of three successive weeks. For each modality in the shade, the shoots diameter and height, and the shoots area of leaves were evaluated after every seven days starting from the day the seedlings were wean and acclimatized for a period of three successive weeks. These vegetative growth stages evaluations were done for six selected explants and seedlings respectively in the greenhouse and the shade according to the method reported by [10].

\subsection{Statistical Analyses}

T. diversifolia leaves and stems effects on the vivoplants growth were analysed by subjection of the variables (the number of shoots, the diameter and heights of shoots and the area of shoots leaves) to a mixed three-way ANOVA performed with XLSTAT software [17]. Each plant is taken as experimental unit and condition, modality and day as factors. Multiple comparisons of the means were done by applying Tukey's test at $5 \%$ probability level. The effect of the $T$. diversifolia leaves and stems on the vivoplants growth from the preemergence and germination stage (the number of shoots) to the vegetative growth stage (the diameter and heights of shoots and the area of shoots leaves) were analysed by the Microsoft Excel 2019. Separations of means were based on Tukey's multiple range tests at a $5 \%$ probability level.

\section{Results}

\subsection{T. diversifolia Leaves and Stems Effects on the Shoots Number}

T. diversifolia leaves and stems were found to significantly $(P<0.0001)$ influence the germination and emergence stage via the number of shoots with a coefficient of determination $\left(\mathrm{R}^{2}\right)$ of $95 \%$ (Table 1). The number of shoots evolves significantly in course of time and the most influential variable was the time. The variables condition, modality and day, as well as the interactions condition and modality, condition and day were highly significant $(P<0.0001)$ while the interaction condition, modality and day was non-significant as shown in Table 1.

The shoot's number was consistently higher in the treated vivoplants which have doubled the quantity of shoots generated compared to the control ones. Regardless of the condition, the shoots number 35 days after weaning was more important in the stem's modality, followed by the leaves and stems modality and the leave's modality (Figure 1(a) and Figure 1(b)). Overall, a significant $(P<$ $0.0001)$ difference was shown between the sterilized substrate (SS) condition and unsterilized substrate (uSS) condition for the shoot's number with two distinguished statistical groups (Figure 2(a)). There was a significant difference between the modality stem's and the modalities leaves and stems and leaves, while 
Table 1. Variance analysis of the growth parameters of plantain vivoplants shoots grown in a substrate amended with Tithonia diversifolia stems and leaves.

\begin{tabular}{|c|c|c|c|c|c|c|c|c|c|}
\hline \multicolumn{2}{|l|}{$\begin{array}{c}\text { Number of shoots } \\
R^{2}=95 \%\end{array}$} & \multicolumn{2}{|c|}{$\begin{array}{l}\text { Diameter }(\mathrm{mm}) \\
\qquad \mathrm{R}^{2}=91 \%\end{array}$} & \multicolumn{2}{|c|}{$\begin{array}{c}\text { Height }(\mathrm{cm}) \\
\mathrm{R}^{2}=96 \%\end{array}$} & \multicolumn{2}{|c|}{$\begin{array}{l}\text { Area of leaves }\left(\mathrm{mm}^{2}\right) \\
\qquad \mathrm{R}^{2}=100 \%\end{array}$} & \multirow[b]{2}{*}{$\mathrm{F}$} & \multirow[b]{2}{*}{$P$} \\
\hline Source & $\mathrm{DF}$ & $\mathrm{F}$ & $P$ & $\mathrm{~F}$ & $P$ & $\mathrm{~F}$ & $P$ & & \\
\hline Condition & 1 & 57.990 & $<0.0001$ & 16.417 & 0.000 & 24.125 & $<0.0001$ & 2467.598 & $<0.0001$ \\
\hline Modality & 3 & 88.648 & $<0.0001$ & 155.558 & $<0.0001$ & 450.552 & $<0.0001$ & 19708.078 & $<0.0001$ \\
\hline Time (Days) & 3 & 247.757 & $<0.0001$ & 35.073 & $<0.0001$ & 19.267 & $<0.0001$ & 6219.244 & $<0.0001$ \\
\hline Condition ${ }^{*}$ Modality & 3 & 1.253 & 0.298 & 6.344 & 0.001 & 34.674 & $<0.0001$ & 304.947 & $<0.0001$ \\
\hline Condition ${ }^{\star}$ Time (Days) & 3 & 5.213 & 0.003 & 0.153 & 0.928 & 0.407 & 0.748 & 218.719 & $<0.0001$ \\
\hline Modality * Time (Days) & 9 & 5.389 & $<0.0001$ & 0.640 & 0.758 & 0.225 & 0.990 & 40.431 & $<0.0001$ \\
\hline Condition ${ }^{\star}$ Modality ${ }^{\star}$ Time & 9 & 0.389 & 0.936 & 0.108 & 0.999 & 0.290 & 0.975 & 85.609 & $<0.0001$ \\
\hline
\end{tabular}

Values in bold correspond to tests where the null hypothesis is not accepted with a significance level alpha $=0.05$. DF is the degree of freedom; $F$ is the value of $\mathrm{F}$ test and $P$ is the probability.

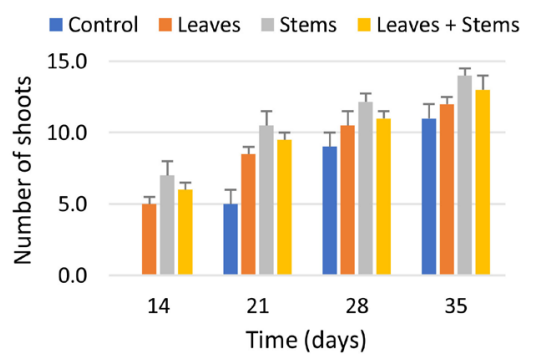

(a)

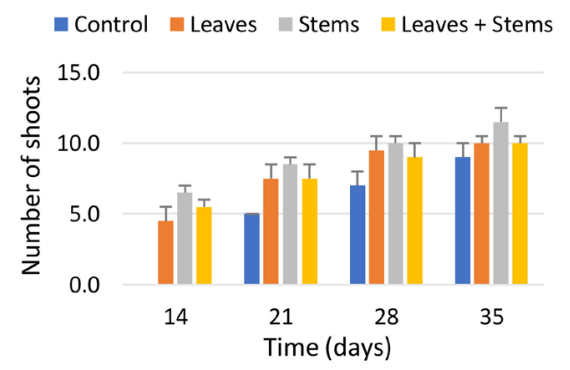

(b)

Figure 1. Evolution in course of time of the number of plantain vivoplants shoots grown on a substrate amended with Tithonia diversifolia stems and leaves in the greenhouse under sterilized substrate condition (a) and unsterilized substate condition (b). Each point represents the average mean of six replicates with the standard deviation for each treatment.

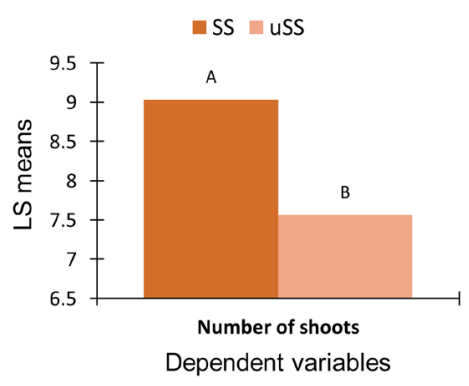

(a)

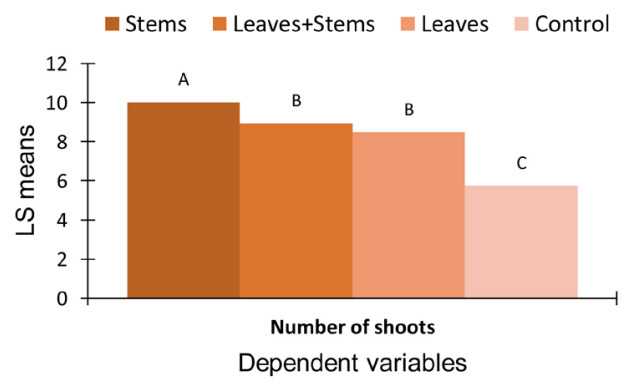

(b)

Figure 2. Least Squares (LS) means summary of the number of plantain vivoplants shoots grown on a substrate amended with Tithonia diversifolia stems and leaves in the greenhouse: Condition (a), Modality (b). Letters A, B and C represent different statistical groups defined by the Tukey test (5\%).

all of them were statistically different to the control, leading to three distinguished statistical groups (Figure 2(b)). Among the three T. diversifolia modalities, the one that showed the best effect in terms of shoot's number was stem's modality (Figure 2(b)). 


\subsection{T. diversifolia Leaves and Stems Effects on the Shoots Diameter, Height and Area of Leaves}

T. diversifolia leaves and stems were found to significantly $(P<0.0001)$ influence the shoots diameter, height and area of leaves with a coefficient of determination $\left(\mathrm{R}^{2}\right)$ of $91 \%, 96 \%$ and $100 \%$ respectively (Table 1 ). The shoot's diameter, height and area of leaves evolve significantly in course of time and the most influential variable was the modality. The variables condition, modality and day, as well as the interaction condition and modality were highly significant $(P<$ $0.0001)$ for the shoot's diameter and height, while all the variables were highly significant $(P<0.0001)$ for the shoot's area of leaves as shown in Table 1.

The shoots diameter, height and area of leaves were consistently higher in the treated vivoplants compared to the control ones. Regardless of the condition, the shoots diameter, height and area of leaves 35 days after weaning were more important in the stem's modality, followed by the leaves and stems modality and the leave's modality (Figures 3-5). Overall, for the three vivoplants shoots response to treatment (diameter, height and area of leaves) a significant difference was shown between the sterilized substrate (SS) condition and unsterilized substrate (uSS) condition with two distinguished statistical groups (Figure 6(a)). In

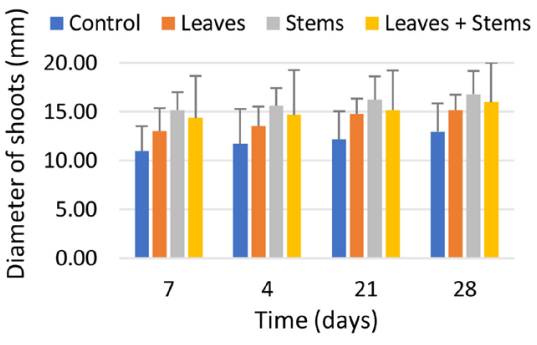

(a)

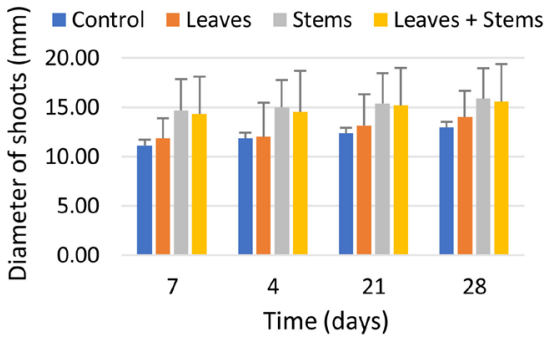

(b)

Figure 3. Evolution in course of time of the diameter of plantain vivoplants shoots grown on a substrate amended with Tithonia diversifolia stems and leaves in the greenhouse under sterilized substrate condition (a) and unsterilized substate condition (b). Each point represents the average mean of six replicates with the standard deviation for each treatment.

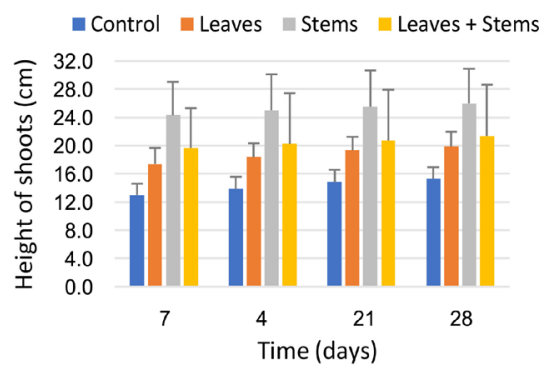

(a)

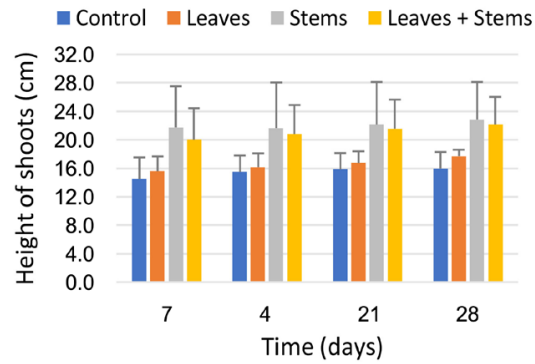

(b)

Figure 4. Height of plantain vivoplants shoots evolution in course of time, grown on a substrate amended with Tithonia diversifolia stems and leaves in the greenhouse under sterilized substrate condition (a) and unsterilized substate condition (b). Each point represents the average mean of six replicates with the standard deviation for each treatment. 


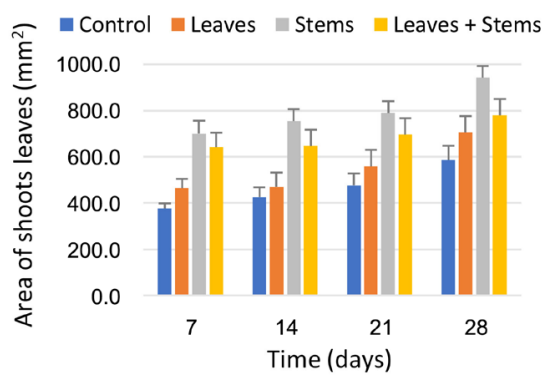

(a)

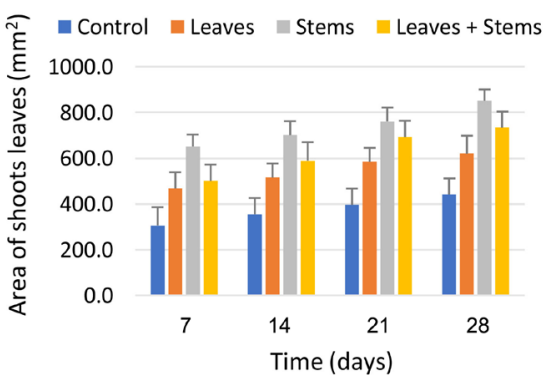

(b)

Figure 5. Evolution in course of time of the leaves area of plantain vivoplants shoots grown on a substrate amended with Tithonia diversifolia stems and leaves in the greenhouse under sterilized substrate condition (a) and unsterilized substate condition (b). Each point represents the average mean of six replicates with the standard deviation for each treatment.

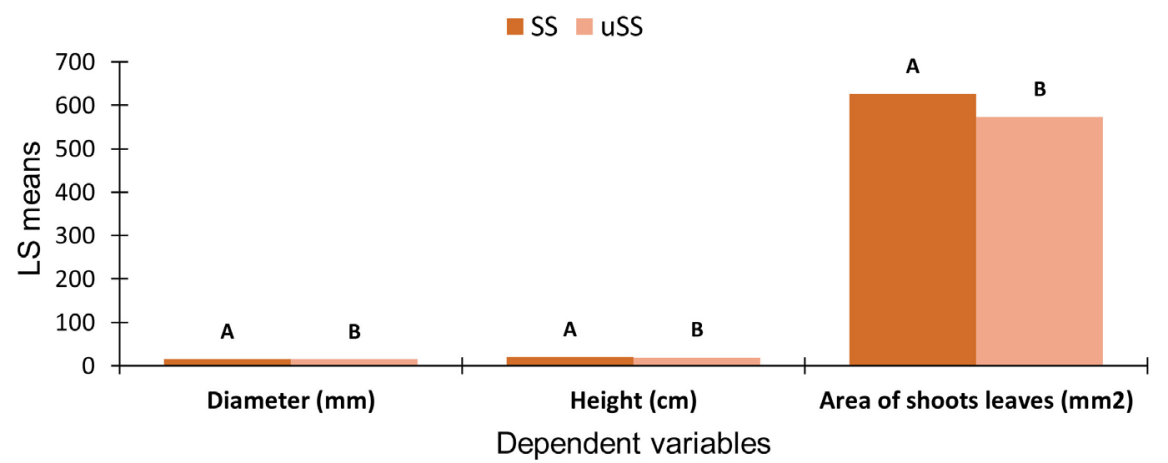

(a)

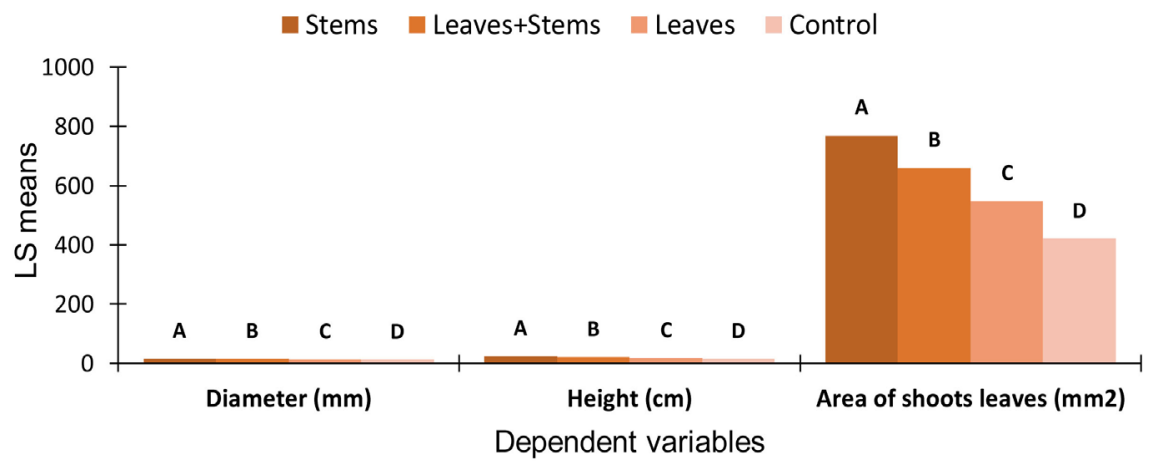

(b)

Figure 6. Least Squares (LS) means summary of the diameter, the height and the area of leaves of plantain vivoplants shoots grown on a substrate amended with Tithonia diversifolia stems and leaves in the greenhouse: Condition (a); Modality (b). Letters A, B, C and $\mathrm{D}$ represent different statistical groups defined by the Tukey test (5\%).

the same line, there was a significant difference between the modality stems, the modality leaves, and the modality stems and leaves; while all of them were statistically different to the control, leading to four distinguished statistical groups (Figure 6(b)). Among the three T. diversifolia modalities, the one that showed the best effect in terms of growth promotion of shoots diameter, height and area 
of leaves was stems modality (Figure 6(b)).

The different treatments of $T$. diversifolia protect the vivoplants against BSD with a level of $80 \%$ protection compared to the controls, and increased synthesis of phenolic compounds, total protein, peroxidase activity, polyphenol oxidase activity and the amount of $\beta$-1,3-glucanase in shoots before and after infection (Data not shown).

\section{Discussion}

The vegetative growth of plantain vivoplants was significantly increased by the T. diversifolia stems and leaves used as substrate amendment. This growth promotion could be explained by the high contents of macro and micronutrients in $T$. diversifolia leaves and stems, essential for crops growth and positively involved as organic amendments in many physiological processes such as the molecular structure of nucleic acid, the storage functions, the energy transfer processes within the plant and the roots development [18] [19] [20]. Our results are in accordance with previous studies that have highlighted the $T$. diversifolia effects on plantain vivoplants development in nursery [10] [13] [14] [15] [16]. T. diversifolia stem's treatment has consistently increased the shoots number, the shoots diameter and height, as well as the shoot area of leaves, being thus the more efficient. However, it would be interesting to investigate the biochemical and molecular mechanisms involved in this growth promotion.

The soil amendment with $T$. diversifolia leaves and stems has clearly shown direct effects on vivoplants physiology, but could also influence indirectly the substrate in nursery. Indeed, organic amendment has been shown to contribute directly to seedlings growth and yield through nutrients supplementation, and indirectly by modifying soil physical properties such as stability of aggregates and porosity that can improve the roots growth, rhizosphere and stimulate plant growth [21]. The soil amendment with $T$. diversifolia seems to act by influencing the physicochemical and biological properties of the soil as well as the soil microbiome activity. Indeed, it could improve the soil physical, chemical and biological properties for soil fertility enhancement, the increase of microbial activity and the optimization of nutrients absorption by plants [22] [23]. It has been recently shown that $T$. diversifolia treatment improved the soil quality and properties through a decrease of bulk density, increase of organic carbon, total nitrogen, available phosphorus and exchangeable potassium [23]. It will be interesting to assess the effect of $T$. diversifolia amendment on soil properties and microbial community.

The level of growth promotion obtained in this study was lower compared with former studies in nursery on $T$. diversifolia effects on plantain growth promotion (mulch, vertical layers, liquid extract, ...) [13] [14] [15] [16]. Allelopathy is the set of biochemical positive and or negative interactions carried out by plants with each other or with microorganisms. T. diversifolia incorporation in the soil may be allelopathic to plantains vivoplants. Similar negative allelopathic 
effects on germination have been reported on okra, cowpea and Amaranthus cruentus [19] [25] [26] [27]. Moreover, the presence of organic fertilizers in excess could slow down the nutrients release and be toxic to the plantain vivoplants as shown in vitro by the inhibitory and stimulatory effects on germination and growth of the spider plant (Cleome gynandra) [19].

The treatment with the leaves of $T$. diversifolia was the less efficient one in terms of growth promotion regardless of the condition (uSS and SS). Indeed, $T$. diversifolia has been reported to contain a large amount of allelochemicals especially in leaves which inhibit growth of many plants [25]. These allelochemicals or toxins seems to be released by actions of microorganisms during decomposition and may interfere with plants growth processes. The unsterilized substrate (uSS) condition has exhibited the most important allelopathic effect compared to the sterilized substrate (SS) condition where the soil microorganism's population are reduced. This less growth promotion could be linked to the less accumulation of growth biomarkers and defense biomarkers leading to a moderate susceptibility to disease as previously shown in previous studies on plantain vivoplants [10] [13] [14] [15] [16].

\section{Conclusion}

In conclusion, $T$. diversifolia leaves and stems seem to improve the growth promotion of plantain vivoplants and act thus as a green manure. It could thus, be a useful tool to reduce the use of chemical inputs in plantain cultivation and be recommended to small holders' farmer for poverty alleviation and an ecoresponsible agriculture.

\section{Conflicts of Interest}

The authors declare no conflicts of interest regarding the publication of this paper.

\section{References}

[1] Oyerinde, R.O., Otusanya, O.O. and Akpor, O.B. (2009) Allelopathic Effect of Tithonya diversifolia on the Germination, Growth and Cholorophyl of Maize (Zea mays L.). Scientific Research and Essay, 4, 879-888.

[2] Kaho, F., Yemefack, M., Feudjio-Teguefouet, P. and Tchantchouang, J.C. (2011) Effet combiné des feuilles de Tithonya diversifolia et des engrais inorganiques sur les rendements du maïs et les propriétés d'un sol ferralitique au Centre Cameroun. Tropicultura, 29, 39-45.

[3] Kandungu, J., Anjarwalla, P., Mwaura, L., Ofori, D.A., Jammadass, R., Stevenson, P.C. and Smith, P. (2013) "Pesticidal Plant Leaflet" Tithonya diversifolia (Hemsley) A. Gray. Kew Royal Botanic Gardens, World Agroforestry Centre.

[4] Diby, Y.K.S., Tahiri, Y.A., Akpesse, A.A.M., Trabi, C.S. and Kouassi, K.P. (2015) Evaluation de l'effet insecticide de l'extrait aqueux de Tithonia diversifolia (Hemsl.) gray (Asteracee) sur les termites en culture du riz (NERICA 1) au centre de la Cote d'Ivoire. Journal of Animal \& plant Sciences, 25, 3966-3976. 
[5] Chagas-Paula, D.A., Oliveira, R.B., Rocha, B.A. and da Costa, F.B. (2012) Ethnobotany, Chemistry and Biological Activities of the Genus Tithonia (Asteraceae). Chemistry and Biodiversity, 9, 210-235. https://doi.org/10.1002/cbdv.201100019

[6] Umar, O.B., Alex, R.D. and Obukohwo, E.E. (2015) Phytochemical and Proximate Composition of Tithonia diversifolia (Hemsl.) A. Gray. Annals Food Science and Technology, 16, 195-200.

[7] Kerebba, N., Oyedeji, A.O., Byamukama, R., Kuria, S.K. and Oyedeji, O.O. (2019) Pesticidal Activity of Tithonia diversifolia (Hemsl.) A. Gray and Tephrosia vogelii (Hook f.); Phytochemical Isolation and Characterization: A Review. South African Journal of Botany, 121, 366-376. https://doi.org/10.1016/j.sajb.2018.11.024

[8] Lassoudière, A. (2007) Le bananier et sa culture. Editions Quae, 383 p.

[9] FAO (2018) Food and Agriculture Organization of the United Nations. FAO Statistics: Banana. http://www.fao.org/faostat/en/\#data/QC

[10] Ewané, C.A., Ndongo, F., Ngoula, K., Tene Tayo, P.M., Opiyo, S.O. and Boudjeko, T. (2019) Potential Biostimulant Effect of Clam Shells on Growth Promotion of Plantain PIF Seedlings (var. Big Ebanga \& Batard) and Relation to Black Sigatoka Disease Susceptibility. American Journal of Plant Science, 10, 1763-1788. https://doi.org/10.4236/ajps.2019.1010125

[11] Kwa, M. (2003) Activation de bourgeons latents et utilisation de fragments de tige $\mathrm{du}$ bananier pour la propagation en masse de plants en conditions horticoles in vivo. Fruits, 58, 315-328. https://doi.org/10.1051/fruits:2003018

[12] Ewané, C.A., Chillet, M., Castelan, F., Brostaux, Y., Lassois, L., Ngando, E.J., Hubert, O., Chilin-Charles, Y., Lepoivre, P. and de Lapeyre de Bellaire, L. (2013) Impact of the Extension of Black Leaf Streak Disease on Banana Susceptibility to Post-Harvest Diseases. Fruits, 68, 351-365. https://doi.org/10.1051/fruits/2013081

[13] Ewane, C.A., Milawe, C.A., Ndongo, E.F. and Boudjeko, T. (2020a) Influence of Clam Shells and Tithonia diversifolia Powder on Growth of Plantain PIF Seedlings (var. French) and Their Sensitivity to Mycosphaerella fijiensis. African Journal of Agricultural Research, 15, 393-411. https://doi.org/10.5897/AJAR2019.14486

[14] Ewané, C.A., Meshuneke, A., Tatsegouock, R.N. and Boudjeko, T. (2020b) Vertical Layers of Tithonia diversifolia Flakes Amendment Improves Plantain Seedling Performance. American Journal of Agricultural Research, 5, 95. https://doi.org/10.28933/ajar-2020-03-2905

[15] Tatsegouock, R.N., Ewane, C.A., Meshuneke, A. and Boudjeko, T. (2020) Plantain Bananas PIF Seedlings Treatment with Liquid Extract of Tithonia diversifolia Induces Resistance to Black Sigatoka Disease. American Journal of Plant Science, 11, 653-671. https://doi.org/10.4236/ajps.2020.115049

[16] Meshuneke, A., Ewané, C.A., Tatsegouock, R.N. and Boudjeko, T. (2020) Tithonia diversifolia Mulch Stimulates the Growth of Plantain PIF Seedlings and Induces a Less Susceptibility to Mycosphaerella fijiensis in the Nursery. American Journal of Plant Science, 11, 672-692. https://doi.org/10.4236/ajps.2020.115050

[17] Addinsoft (2020) XLSTAT Statistical and Data Analysis Solution. New York. https://www.xlstat.com

[18] Kulcheski, F.R., Côrrea, R., Gomes, I.A., de Lima, J.C. and Margis, R. (2015) NPK Macronutrients and microRNA Homeostasis. Frontiers in Plant Science, 6, 451. https://doi.org/10.3389/fpls.2015.00451

[19] Musyimi, M. and Kahihu, S.W. (2005) Allelopathic Effects of Mexican Sunflower (Tithonia diversifolia (Hemsl) A. Gray) on Germination and Growth of Spider 
Plant (Cleome gynandra L.). Journal of Biodiversity and Environmental Sciences, 2, 26-35.

[20] Goss, M.J., Tubeileh, A. and Goorahoo, D. (2013) A Review of the Use of Organic Amendments and the Risk to Human Health. Advances in Agronomy, 120, 275-379. https://doi.org/10.1016/B978-0-12-407686-0.00005-1

[21] Bell, R.W. and Dell, B. (2008) Micronutrients for Sustainable Food, Feed, Fibre and Bioenergy Production. IFA, Paris, 1-195.

[22] Purbajanti, E.D., Slamet, W., Fuskhah, E. and Rosyida (2019) Effects of Organic and Inorganic Fertilizers on Growth, Activity of Nitrate Reductase and Chlorophyll Contents of Peanuts (Arachis hypogaea L.). IOP Conference Series Earth and Environmental Science, 250, Article ID: 012048.

https://doi.org/10.1088/1755-1315/250/1/012048

[23] Malerba, M. and Cerana, R. (2019) Recent Applications of Chitin- and Chitosan-Based Polymers in Plants. Polymers, 11, 839.

https://doi.org/10.3390/polym11050839

[24] Hafifah, H., Sudiarso, S., Maghfoer, M.D. and Prasetya, B. (2016) The Potential of Tithonia diversifolia Green Manure for Improving Soil Quality for Cauliflower (Brassica oleracea var. Brotrytis L.). Journal of Degraded and Mining Lands Management, 3, 499-506.

[25] Otusanya, O.O., Ilori, O.J. and Adelusi, A.A. (2007) Allelopathic Effect of Tithonia diversifolia (Hemsl) A. Gray on Germination and Growth of Amaranthus cruentus. Research Journal of Environmental Sciences, 1, 285-293.

https://doi.org/10.3923/rjes.2007.285.293

[26] Ademiluyi, B.O. (2012) Effect of Tithonia diversifolia (Hemsl) A. Gray on the Growth and Yield of Okra (Abelmuscus esculentus). Journal of Agricultural Science and Technology, 2, 219-222.

[27] Ademiluyi, B.O. and Ajewole, T.O. (2013) Study on the Effects of Fresh Shoot Biomass of Tithonia diversifolia on the Germination, Growth and Yield of Cowpea (Vigna unguiculata L.). American Journal of Experimental Agriculture, 3, 1005-1011. https://doi.org/10.9734/AJEA/2013/4361 